\title{
Antioxidant and antibacterial properties of bacterial cellulose- Indonesian plant extract composites for mask sheet
}

\author{
Anastasia Wheni Indrianingsih*, Vita Taufika Rosyida, Wuri Apriyana, Septi Nur Hayati, Cici Darsih, Khoirun Nisa, Dwi Ratih
} Research Division for Natural Product Technology, Indonesian Institute of Sciences, Yogyakarta, Indonesia.

\begin{tabular}{l}
\hline ARTICLE INFO \\
\hline Received on: 03/01/2020 \\
Accepted on: 17/05/2020 \\
Available online: 04/07/2020 \\
\hline Key words: \\
Bacterial cellulose, \\
antioxidant, antibacterial, \\
plants extract, face mask \\
sheet.
\end{tabular}

sheet.

\begin{abstract}
Cellulose constructed by microbial culture is called as bacterial cellulose (BC). BC has a high purity with no lignin, pectin, and hemicellulose commonly found in plant cellulose and also has a high degree of crystallinity so that the microfiber contained in it is tightly bound together and forms robust and elastic webbing. This study aims to provide a face mask sheet, wherein the sheets are made from BC, which is obtained from the fermentation of coconut water using Acetobacter xylinum. The plant extracts used were green tea leaf extract (Camellia sinensis), roselle flower petals (Hibiscus sabdariffa), and Hibiscus rosa-sinensis L. flower extract (a red and pink variant of color). The antioxidant assay using the DPPH test for the $\mathrm{BC}$ with plant extracts was evaluated. The result showed that the highest antioxidant activity was owned by BC green tea extract (IC50 80.9 ppm), followed by BC red hibiscus extract (IC50 438.8 ppm), BC roselle extract (IC50 $505.1 \mathrm{ppm}$ ), and BC pink hibiscus extract (IC50 $1015 \mathrm{ppm}$ ). Antibacterial testing was carried out using Salmonella typhimurium, Staphylococcus aureus, Escherichia coli, and Pseudomonas aeruginosa. The growth of bacteria incubated in $\mathrm{BC}$ extract with $37^{\circ} \mathrm{C}$ for 24 hours was carried out by optical density reading (OD) at $600 \mathrm{~nm}$ with ELISA microplate reader. The results obtained showed that, with extract concentrations between 125 and $500 \mathrm{ppm}, \mathrm{BC}$ roselle extract had the highest inhibitory activity against $P$. aeruginosa and E. coli. The BC plant extracts were also characterized using SEM, FTIR, and X-ray diffraction technique for their morphological structure, functional groups, and crystallinity. This result showed that $\mathrm{BC}$ with the addition of plant extracts is a promising candidate for mask sheet application with natural antioxidant and antibacterial activity.
\end{abstract}

\section{INTRODUCTION}

Bacterial cellulose $(\mathrm{BC})$ is a polymer synthesized by microbes. Microbes that usually can synthesize $\mathrm{BC}$ are Gluconacetobacter, Sarcina, and Acetobacter strains (Klemm et al., 2005). The structure of $\mathrm{BC}$ is similar to cellulose from plants. However, the $\mathrm{BC}$ is having advantages than cellulose from plants such as high purity with no content of lignin, pectin, and, hemicellulose, high crystallinity, and excellent biocompatibility (Ross et al., 1991). Many studies have been conducted on BC, and it has application on the biomedical application, such as biosensor, drug delivery, and tissue engineering (Saska et al.,

"Corresponding Author

Anastasia Wheni Indrianingsih, Research Division for Natural Product Technology, Indonesian Institute of Sciences, Yogyakarta, Indonesia. E-mail: anastasia.wheni.i@gmail.com
2011; Watanabe et al., 1998). The hydroxyl groups in BC also become a benefit since it made $\mathrm{BC}$ appropriate to be modified with other materials, such as the mechanical and physical properties, which can be improved by making composites with other materials such as collagen, chitosan, and gelatin (Culebras et al., 2015; Lin et al., 2013; Shah et al., 2013). BC is also a potential candidate for health and cosmetic applications because it has good water-holding ability and nanofibrous network with many pores (Pal et al., 2017). However, BC needed to be modified with some antibacterial agents or other biologically active compounds to make it applicable in health or cosmetic applications since it does not show any antibacterial activity itself.

Face masks with a sheet type are generally printed to form a face pattern. Usually, a cosmetic liquid was impregnated into a sheet-type mask. The liquid cosmetic ingredients in the sheet masks are formulated according to the skin type. There are 16 types of classified skin based on the skin properties (Baumann, 2008). This active ingredient of cosmetics can work on the skin 
with a longer time compared to usual cosmetic liquids and has several functions such as moisturizers, lightening, exfoliants, and vitamins to facilitate a healthy skin (Nilforoushzadeh et al., 2018; Youn et al., 2002). A face mask is essential since it will affect the condition of the skin, which is an essential factor of human health (Yu et al., 2016).

Herbal ingredients in the cosmetics industry are important because of their biological functions that provide nutrients for healthy skin such as antioxidants and antiinflammatory (Nohynek et al., 2010; Yeom et al., 2011). Besides its functions as active ingredients and nutrients in cosmetics, the active biological compounds from herbal as antimicrobial and antioxidant could also be used as a natural preservative in the products (Jridi et al., 2014). The secondary metabolites of edible plants, i.e., polyphenols, flavonoids, and essential oils usually consist of bioactive compounds with antibacterial or antioxidant activity and increase the interest of researchers (Sanchez-Gonzalez et al., 2011). Several studies had shown that the impregnation of plant extracts into films could enhance their functional and physical characteristics (Bitencourt et al., 2014; Gimenez et al., 2013). A research by Siddhan et al. (2016) also revealed that the incorporation of Momordica charantia extract, Tridax procumbens extract, and chitosan demonstrated a good antibacterial activity.

Indonesia produces much coconut, which also produces a lot of coconut water waste. However, usually, people use coconut water only for food and drinks such as nata de coco (Nugroho et al., 2015; Zhang et al., 2017). Besides, herbal plants in Indonesia also have many variations and active compounds, but not many have been exploited in the field of cosmetics, especially facial masks. This study aims to make a face mask from coconut water waste that is widely available in Indonesia, with the addition of active local Indonesian herbal ingredients, and evaluate their antibacterial and antioxidant properties. To the best of authors' knowledge, this is the first study about the utilization of coconut water waste in Indonesia for a face mask sheet with the addition of several local Indonesian plant extracts including green tea (Camellia sinensis), rosella petals (Hibiscus sabdariffa), and a red and pink variant of hibiscus flowers (Hibiscus rosa-sinensis).

\section{MATERIAL AND METHODS}

\section{Reagents}

Salmonella typhimurium (strain FNCC-0165), Staphylococcus aureus (FNCC-0047), Escherichia coli (strain FNCC- 194), Acetobacter xylinum (strain FNC-0001) and Pseudomonas aeruginosa were obtained from Gadjah Mada University, Indonesia. Hibiscus sabdariffa, H. rosa-sinensis, C. sinensis, and coconut water were obtained from Yogyakarta. Acetic acid, yeast extract, $\mathrm{NaOH}$, sucrose, plate count agar, and universal $\mathrm{pH}$ paper were obtained from Merck.

\section{Media culture and bacterial cellulose production}

\section{Preparation of $B C$ thin sheets}

The preparation of $\mathrm{BC}$ was performed by using $\mathrm{A}$. xylinum as a starter (Almeida et al., 2014; Indrianingsih et al., 2017). The propagation of seedlings was carried out from a volume of $10 \mathrm{ml}$ of media developed into $100 \mathrm{ml}$ of media and $500 \mathrm{ml}$ of coconut water media, each with a culture time of approximately 7 days. Coconut water, which had been separated from the impurity, was heated at a temperature of $100^{\circ} \mathrm{C}-105^{\circ} \mathrm{C}$ on a heating plate with a magnetic stirrer for 8-12 minutes. Acetic acid with the levels of $18 \%-22 \%$ of $20 \mathrm{ml}, 50 \mathrm{~g}$ of sucrose, $5 \mathrm{~g}$ of urea, and extracts of green tea, rosella petals, red, and pink variant of $H$. rosasinensis of $10 \% \mathrm{~b} / \mathrm{v}$ were added to the coconut water solution and stirred. The sterilization of the solution was conducted at $121^{\circ} \mathrm{C}$ for 15 minutes using an autoclave. After cooling, the solution was poured into a fermentation container, and a starter of $8 \%-12 \%$ was poured. The solution was incubated for 1 week at $27^{\circ} \mathrm{C}-30^{\circ} \mathrm{C}$. During storage, there should be no shock to the container so that the $\mathrm{BC}$ layer grows well. BC obtained from fermented products was sterilized in a wet sterilizer at $121^{\circ} \mathrm{C}$ for 15 minutes to kill microbial remnants. Furthermore, BC was washed thoroughly with tap water until neutral $\mathrm{pH}$ and dried at room temperature.

\section{Morphological analysis}

BC thin sheets were analyzed its surface using SEM (SU-3500 Hitachi, Japan). It was operated at $15 \mathrm{kV}$ with 10,000 magnifications. The X-ray diffraction technique (XRD) (Rigaku Smartlab) was used to study the structure and crystallinity. It was performed at $30 \mathrm{~mA}$ and $40 \mathrm{kV}$, with the source of $\mathrm{Cu}-\mathrm{K} \alpha$ radiation $(\lambda=1.5418 \AA$ ). The functional groups of $\mathrm{BC}$ thin sheets were evaluated using FTIR (8201 PC Shimadzu, Japan). It was performed at a frequency of $4,000-400 \mathrm{~cm}^{-1}$.

\section{Swelling capacity}

The swelling capacity of the $\mathrm{BC}$ thin sheet was performed by immersing it in distilled water for 72 hours (Maneerung et al., 2008). It was in a size of $2 \mathrm{~cm}$ width $\times 2 \mathrm{~cm}$ length. The swelling capacity was determined as follows:

\section{Swelling $=\left(G_{\mathrm{s}, \mathrm{t}}-G_{\mathrm{i}}\right) / G_{\mathrm{i}}$}

where $G_{\mathrm{s}, \mathrm{t}}$ is the weight of sample in a swollen state and $G_{\mathrm{i}}$ is the initial weight of dried sample.

\section{DPPH assay}

The BC composite was macerated in ethanol for 24 hours. After evaporation, the BC plant composite extracts were diluted in methanol. DPPH solution in methanol $(1.01 \mathrm{mM})$ was then added to the solution. The reaction was kept for 30 minutes at a dark room temperature. The scavenging activity was evaluated by measuring its absorbance at $517 \mathrm{~nm}$ using an ELISA reader (Yen and Chen, 1995). The equation for calculating scavenging activity was as follows:

$$
\text { DPPH scavenging activity }(\%)=\left(\frac{A_{0}-A_{1}}{A_{0}} \times 100\right)
$$

where $A_{1}$ was sample's absorbance and $A_{0}$ was the control's absorbance.

\section{Antibacterial activity evaluation of BC masks}

Antibacterial testing was carried out using $S$. typhimurium, S. aureus, E. coli, and P. aeruginosa and evaluated using growth curve assay using the previously described method (Huang et al., 2017). The growth of bacteria incubated in BC 
extract with $37^{\circ} \mathrm{C}$ for 24 hours was carried out by optical density (OD) reading at $600 \mathrm{~nm}$ with ELISA microplate reader.

\section{Statistical analysis}

In this study, all experiments were performed thrice. The SPPS 16.0 with the analysis of variance followed by Duncan's test was used for the statistical analysis program. The significant difference was achieved at a level of $p<0.05$.

\section{RESULT AND DISCUSSION}

\section{Morphology of BC thin sheet}

The surface of BC thin sheet was evaluated using SEM. Figure 1 shows the SEM image of the dried BC thin sheet. From

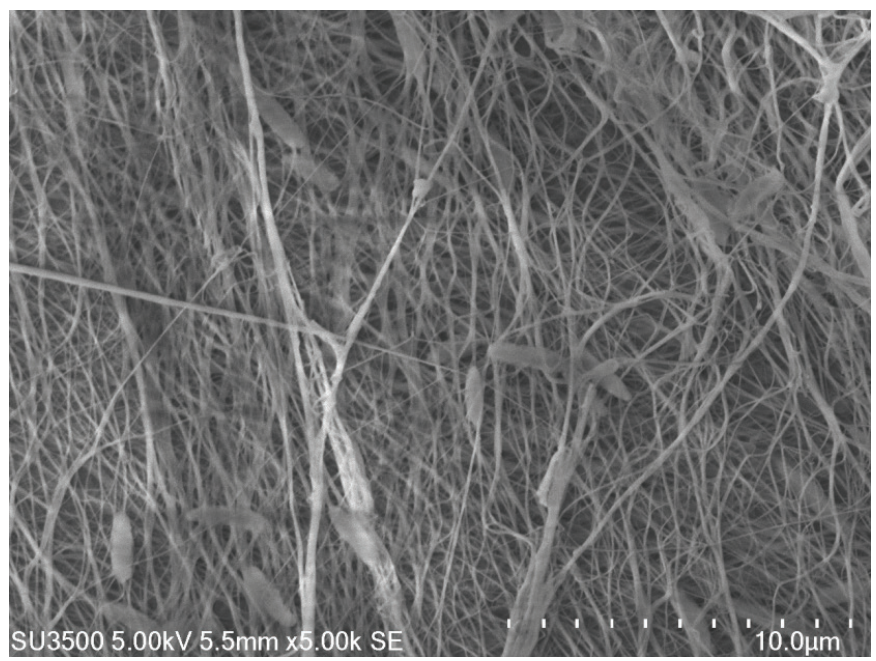

Figure 1. SEM images of the surface morphological structure of dried bacterial cellulose film. the SEM image, the surface of bacterial cellulose was composed of many neat fibrils and makes an aggregated structure. It has a fibril width between 20 and $50 \mathrm{~nm}$ in size. The nanometer-sized fibrils were interconnected and form a 3D network. A previous study also revealed that $\mathrm{BC}$ had neat fibrils that overlap and make a layer like ribbons (Indrianingsih et al., 2017; Nadia et al., 2012).

\section{$\mathrm{X}$-ray diffractogram of BC plant extract composites}

$\mathrm{X}$-ray diffraction technique (XRD) was conducted to evaluate the crystallinity structure of BC plant extract sheet. This technique was commonly performed for analysis of the material crystallinity as well as the ratio of crystallinity to the amorphous state. In Figure 2, the diffractogram of the BC plant extract was shown. The diffractogram presented the crystallinity degree of $\mathrm{BC}$ green tea, $\mathrm{BC}$ rosella; $\mathrm{BC} H$. rosa-sinensis var. pink, and $\mathrm{BC} H$. rosa-sinensis var red, which has slightly different. The presence of peaks at $2 \Theta$ of $14.6,16.9,22.7$, and $27.9^{\circ}$ was indicated the diffraction planes of (101), (111), (002), and (130), respectively. It was the Miller indices of cellulose (Zhu et al., 2014). The higher and sharper peak of the diffractogram formed, and it could be indicated a higher potential of its crystallinity. The diffractogram peaks observed in $\mathrm{BC}$ plant extracts showed a broad peak that indicated that the $\mathrm{BC}$ film was not entirely a crystalline material. The plant extract added to the $\mathrm{BC}$ possibly caused the decrease of its crystallinity.

\section{Profile of infrared spectrum BC masks}

The results of the infrared spectrum for $\mathrm{BC}$ plant extract composite by the addition of extracts of natural ingredients are shown in Figure 3 with a wavelength of around $500-4000 \mathrm{~cm}^{-1}$. In the IR spectrum of $\mathrm{BC}$ green tea composite, the vibrations of hydroxyl $(\mathrm{O}-\mathrm{H})$ in water, phenol, and alcohol were shown with a band at $3,410 \mathrm{~cm}^{-1}$. The band absorption around 2,924 and 2,854 $\mathrm{cm}^{-1}$ indicated the $\mathrm{C}-\mathrm{H}$ stretch in alkanes and $\mathrm{O}-\mathrm{H}$ stretch in a

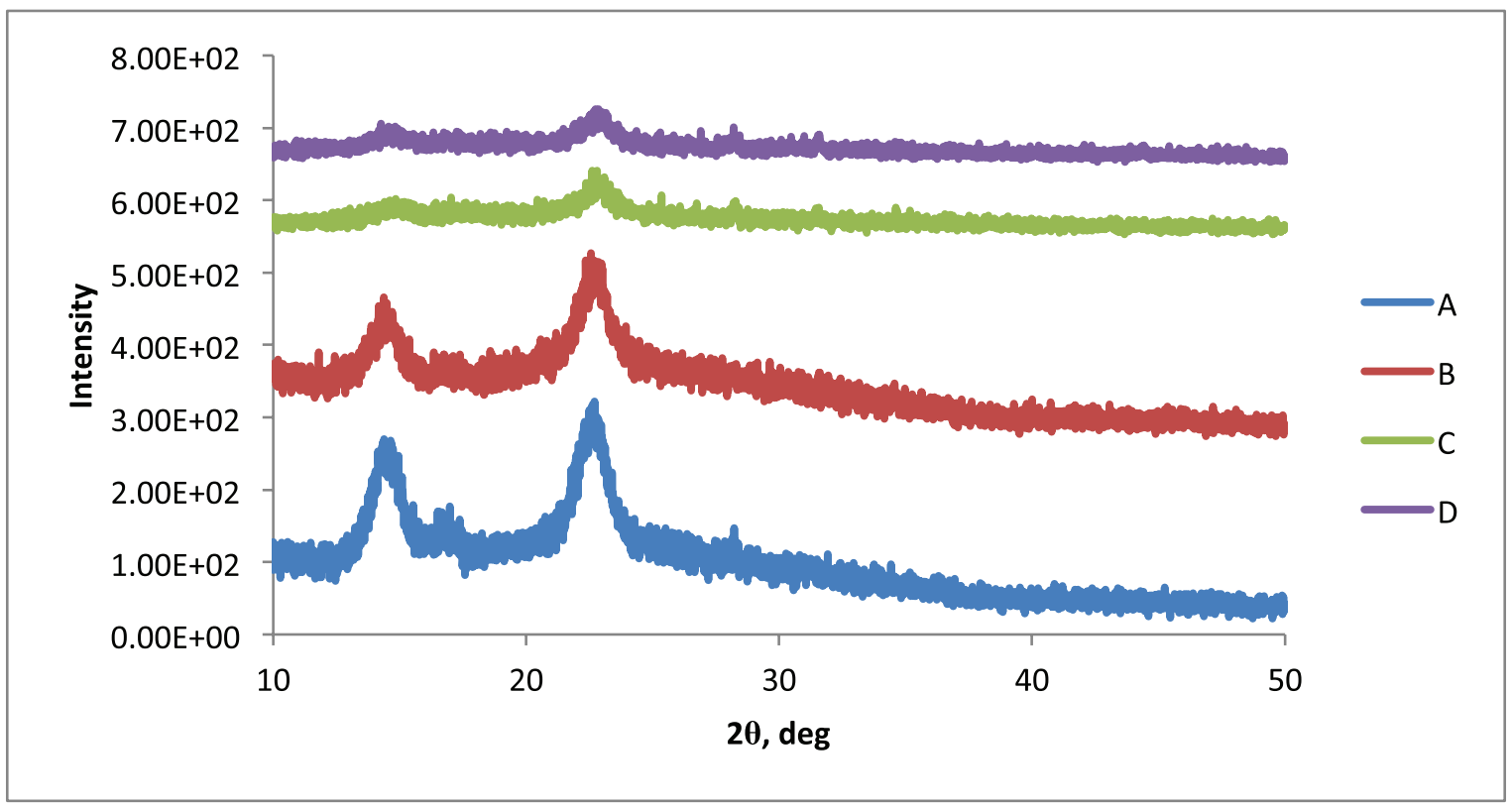

Figure 2. Diffractogram of $\mathrm{BC}$ plant extract mask. (A) BC green tea; (B) BC rosella; (C) BC H. rosa-sinensis var. pink; and (D) $\mathrm{BC} H$. rosa-sinensis var red. 
carboxylic acid. The absorption peak at $1,635 \mathrm{~cm}^{-1}$ was possibly the $\mathrm{C}=\mathrm{C}$ vibration and $\mathrm{C}=\mathrm{O}$ vibration in polyphenols; meanwhile, the band absorption around $1,373 \mathrm{~cm}^{-1}$ possibly came from $\mathrm{C}-\mathrm{N}$ vibration of amide-I. The $\mathrm{C}-\mathrm{O}$ vibration from amino acid gave a band at $1,064 \mathrm{~cm}^{-1}$. Moreover, the absorption around $894 \mathrm{~cm}^{-1}$ was possibly from $\mathrm{C}-\mathrm{H}$ bending. Thus, from the IR spectrum, it could be observed that $\mathrm{BC}$ green tea composite was possibly rich in carboxylic acid, polyphenols, proteins, and amino acid. This result of spectra was in agreement with the literature (Senthilkumar et al., 2014).

In the IR spectrum, the wavelengths around $1,651 \mathrm{~cm}^{-1}$ indicated the presence of glucose carbonyl groups from BC. This uptake experienced a shift in the addition of green tea extract, red hibiscus, and pink hibiscus flowers to a wavelength of around $1,635 \mathrm{~cm}^{-1}$. In the $\mathrm{BC}$ roselle thin layer, anthocyanin aglycones were generally observed at $1,800-1,380 \mathrm{~cm}^{-1}$ absorption. The broad peak around $3,371 \mathrm{~cm}^{-1}$ was the characteristic of the hydrogen bond (-OH). The absorption band at 2,368-2,337 $\mathrm{cm}^{-1}$ indicated the presence of a conjugated aromatic ring supported by an absorption band at $1,064 \mathrm{~cm}^{-1}$ from the symmetrical C-O-C functional group. In the $\mathrm{BC}$ green tea thin layer, the band at 3,410 $\mathrm{cm}^{-1}$ was a vibrational result of the $\mathrm{O}-\mathrm{H}$ group found in water, ethanol, and phenol and also the stretching of $\mathrm{N}-\mathrm{H}$ from the amine group. The vibration of C-H in alkanes and $\mathrm{O}-\mathrm{H}$ in carboxylic acids appeared at 2,924 and 2,854 $\mathrm{cm}^{-1}$, respectively. In the thin $\mathrm{BC}$ red hibiscus and pink hibiscus flowers, there were a few similarities in the infrared absorption. The absorption peak at $3,387 \mathrm{~cm}^{-1}$ in red hibiscus flowers and $3,425 \mathrm{~cm}^{-1}$ in pink flower $\mathrm{BC}$ showed the absorption of $\mathrm{O}-\mathrm{H}$ groups of polysaccharide compounds. The absorption band at $2,931 \mathrm{~cm}^{-1}$ in both the red and pink hibiscus flowers showed the asymmetric $\mathrm{C}-\mathrm{H}$ vibrations of the suberin compound. The stretching of C-C and C-O from polysaccharide compounds was shown in $1,111 \mathrm{~cm}^{-1}$ uptake in both the red and pink BCs. The C-O vibration of the polysaccharide was shown in the absorption of $1,057 \mathrm{~cm}^{-1}$ in both the red and pink BCs.

\section{Antioxidant activity of $\mathrm{BC}$ masks}

The $\mathrm{BC}$ extraction process, with the addition of natural extract, was carried out by the maceration method using an ethanol solvent for 24 hours. The filtrate was evaporated to obtain the $\mathrm{BC}$ roselle extract, $\mathrm{BC}$ green tea, $\mathrm{BC}$ red hibiscus, and $\mathrm{BC}$ pink hibiscus flower. The results of testing the antioxidant activity of $\mathrm{BC}$ masks according to this invention were expressed with IC50 values (Table 1). The high antioxidant activity was owned by $\mathrm{BC}$ green tea extract (IC50 $80.9 \mathrm{ppm}$ ), followed by red hibiscus BC extract (IC50 $438.8 \mathrm{ppm}$ ), BC roselle extract (IC50 $505.1 \mathrm{ppm}$ ), and BC extract of pink hibiscus (IC50 $1015 \mathrm{ppm}$ ). Green tea (C. sinensis) contained catechin compounds (in the form of epicatechin, epicatechin gallate, epigallocatechin, and epigallocatechin gallate) which were known to have antioxidant activity, caffeine, theophylline, theobromine and geraniol, linalool, benzyl alcohol, and phenyl ethanol. The roselle petals (H. sabdariffa) contained many antioxidant compounds, namely, anthocyanin, delfidine, cyanidin, esculetin, and Vitamin C. Besides, the roselle petals also contained Vitamin B, calcium, beta carotene, essential amino acids, and plant acids (15\%-20\%) such as malic acid, citric acid, tartrate acid, and also hydroxy citric acid. Other research results showed that hibiscus extract contained compounds that had antioxidant activities, including quercetin, quercetin glycosides, malvalic acid, beta carotene, and gentisic acid.

Table 1. Antioxidant activity of BC plant extract on DPPH scavenging assay.

\begin{tabular}{lc}
\hline BC plant extracts & IC50, $\mathbf{p p m}$ \\
\hline H. sabdariffa & $505.9 \pm 8.1 \mathrm{c}$ \\
C. sinensis & $80.98 \pm 2.2 \mathrm{a}$ \\
H. rosa-sinensis var. red & $438.81 \pm 7.8 \mathrm{~b}$ \\
H. rosa-sinensis var. pink & $1,015.67 \pm 9.8 \mathrm{~d}$ \\
\hline
\end{tabular}

Each value represents the mean of triplicate measurements; different letter means a significant difference in $p<0.05$.

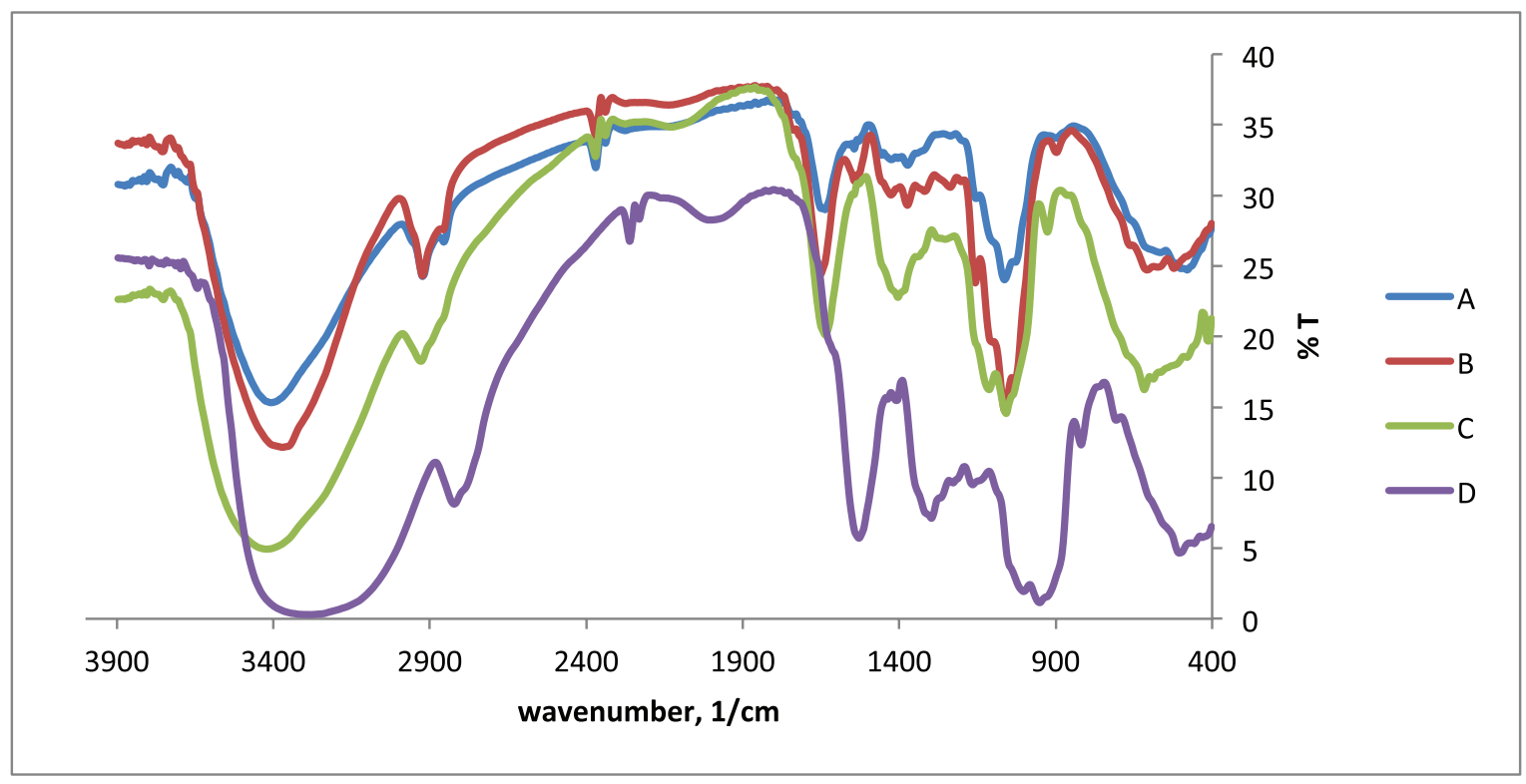

Figure 3. Spectra of BC plant extract mask. (A) BC green tea; (B) BC rosella; (C) BC H. rosa-sinensis var. pink; (D) BC H. rosa-sinensis var red. 

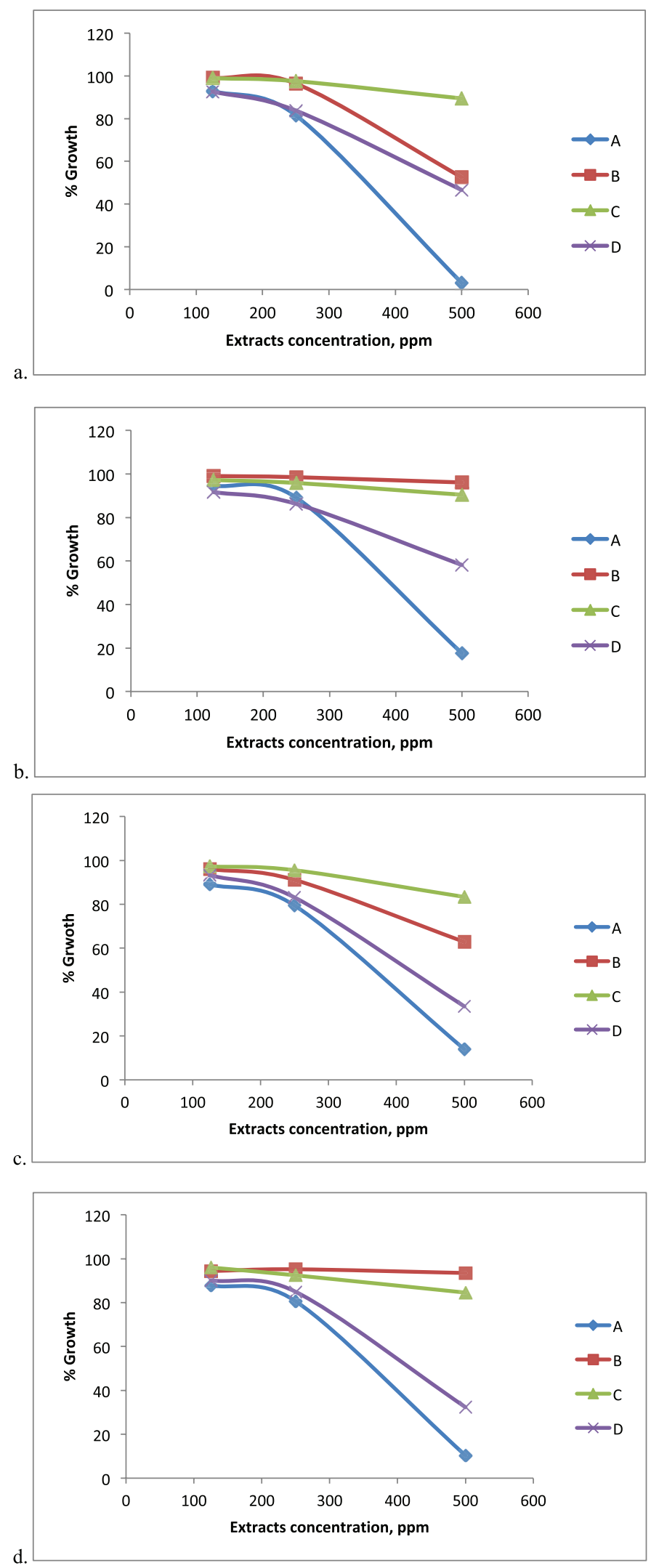

Figure 4. Growth curve of bacteria: a. P. aeruginosa; b. S. typhimurium; c. E. coli ; d. S. aureus against plant extract of rosella (A), H. rosa-sinensis var red (B), $H$. rosa-sinensis var pink (C), and green tea (D).

\section{Antibacterial activity of BC masks}

The antibacterial activity of BC plant extract masks against S. typhimurium, S. aureus, E. coli, and P. aeruginosa is shown in Figure 4. The results obtained showed that, with extract concentrations between 125 and $500 \mathrm{ppm}$, for the inhibitory growth activity of $P$. aeruginosa and E. coli, BC roselle extract had the highest inhibitory activity, followed by green tea extract, red hibiscus flowers, and pink hibiscus flowers; whereas for the growth inhibition activities of $S$. typhimurium and $S$. aureus, roselle extract also had the highest inhibitory activity, followed by green tea extract, $H$. rosa-sinensis var. pink, and $H$. rosa-sinensis var. red. The in vitro tests of some of these natural products also showed inhibitory activity against several pathogens such as Salmonella sp., E. coli, P. aeruginosa, B. subtilis, Streptococcus sp. and S. aureus (Ruban et al., 2012). Some compounds that were considered responsible for antibacterial activity include flavonoids, tannins, alkaloids, and triterpenoids. The activity was related to the ability of these compounds to form complexes with extracellular components, dissolved proteins, and bacterial cell walls. Through this research, it was intended to integrate the extract of natural products into the appropriate fermentation media to form the efficacy of a face mask product containing BC. However, the future studies about the formulation of liquid cosmetic and active extract ingredients and its sensory test on volunteer such as its adhesion to the skin and improvement of skin moisture should be conducted for the industrial applications. Moreover, the stability and storage studies of the BC plant extract mask should be conducted in the next future for measuring its shelf-life.

\section{CONCLUSION}

This study showed that several BC extracts from plants had been synthesized successfully. It performed a good antioxidant activity using DPPH radical scavenging assay and also good antibacterial activity against $S$. typhimurium, S. aureus, E. coli, and $P$. aeruginosa. The SEM image also revealed that $\mathrm{BC}$ thin sheet had pores in a 3D network of neat fibrils. From this study, BC thin sheet from coconut water waste may be used as a promising candidate for the mask sheet. Future research on its formulation, sensory test, and shelf-life performance should be evaluated.

\section{ACKNOWLEDGMENT}

The project was supported by "Riset Unggulan LIPI" Project (Indonesian Institute of Sciences) in 2017.

\section{CONFLICT OF INTERESTS} in this research.

The authors declare that there was no conflict of interest

\section{REFERENCES}

Almeida IF, Pereira T, Silva NHCS, Gomes FP, Silvestre AJD, Freire CSR, Sousa Lobo JM, and Costa PC. Bacterial cellulose membranes as drug delivery systems: An in vivo skin compatibility study. Eur J Pharm Biopharm, 2014; 86:332-6.

Baumann L. Understanding and treating various skin types: the Baumann skin type indicator. Dermatol Clin, 2008; 26(3):359-73.

Bitencourt CM, Favaro-Trindade CS, Sobral, PJA, Carvalho RA. Gelatin-based films additive with Curcuma ethanol extract: antioxidant activity and physical properties of films. Food Hydrocoll, 2014; 40:145-52. 
Culebras M, Grande CJ, Torres FG, Troncoso OP, Gomez CM, Bano MC. Optimization of cell growth on bacterial cellulose by adsorption of collagen and poly-L-lysine. Int J Polym Mater Po, 2015; 64(8):411-5.

Gimenez B, Lacey AL, Perez-Santin E, Lopez-Caballero M E, Montero P. Release of active compounds from agar and agar-gelatin films with green tea extract. Food Hydrocoll, 2013; 30:264-71.

Huang W, Wang JQ, Song HY, Zhang Q, Liu GF. Chemical analysis and in vitro antimicrobial effects and mechanism of action of Trachyspermum copticum essential oil against Escherichia coli. Asian Pac J Trop Med, 2017; 10(7):663-9.

Indrianingsih AW, Rosyida VT, Jatmiko TH, Prasetyo DJ, Poeloengasih CD, Apriyana W, Nisa K, Nurhayati S, Hernawan, CDarsih, Pratiwi D, Suwanto A, Ratih D. Preliminary study on biosynthesis and characterization of bacteria cellulose films from coconut water. IOP Conf Ser Earth Environ Sci, 2017; 101(012010):1-8.

Jridi M, Hajji S, Ayed HB, Lassoued I, Mbarek A, Kammoun M, Nasri M. Physical, structural, antioxidant and antimicrobial properties of gelatin-chitosan composite edible films. Int J Biol Macromol, 2014; 67:373-9.

Klemm D, Heublein B, Fink HB, Bohn A. A Cellulose: fascinating biopolymer and sustainable raw material. Angew Chem Int Ed, 2005; 44:3358-93.

Lin WC, Lien CC, Yeh HJ, Yu CM, Hsu SH. Bacterial cellulose and bacterial cellulose chitosan membranes for wound dressing applications. Carbohydr Polym, 2013; 94(1):603-11.

Maneerung T, Tokura S, Rujiravanit R. Impregnation of silver nanoparticles into bacterial cellulose for antimicrobial wound dressing. Carbohydr Polym, 2008, 72:43-51.

Nadia H, Amin MCIM, Ishak A. Physicochemical properties and characterization of nata de coco from local food industries as a source of cellulose. Sains Malays, 2012; 41:205-11.

Nilforoushzadeh MA, Amirkhani MA, Zarrintaj P, Abolfazl Salehi Moghaddam AS, Tina Mehrabi T, Shiva Alavi S, Sisakht MM. Skincare and rejuvenation by cosmeceutical facial mask. J Cosmet Dermatol, 2018; 2018:1-10.

Nohynek GJ, Antignac E, Re T, Toutain H. Safety assessment of personal care products/cosmetics and their ingredients. Toxicol Appl Pharmacol, 2010; 243(2):239-59.

Nugroho DA, Aji P. Characterization of Nata de Coco Produced by Fermentation of Immobilized Acetobacter xylinum. Agric Agric Sci Procedia, 2015; 3:278-82.

Pal S, Nisi R, Stoppa M, Licciulli A. Silver-functionalized bacterial cellulose as an antibacterial membrane for wound-healing applications. ACS Omega, 2017; 2:3632-9.

Ruban P, Gajalakshmi K. In vitro antibacterial activity of Hibiscus rosa-sinensis flower extract against human pathogens. Asian Pac J Trop Biomed, 2012; 2(5):399-403.

Ross P, Mayer R, Benziman M. Cellulose biosynthesis and function in bacteria. Microbiol Rev, 1991; 55:35-58.
Sanchez-Gonzalez L, Vargas M, Gonzalez-Martinez C, Chiralt A, Chafer M. Use of essential oils in bioactive edible coatings: a review. Food Eng Rev, 2011; 3(1):1-16.

Saska S, Barud HS, Gaspar AMM, Marchetto R, Ribeiro SJL, Messaddeq Y. Bacterial cellulose-hydroxyapatite nanocomposites for bone regeneration. Int J Biomater, 2011; 2011:1-8.

Senthilkumar SR, Sivakumar T. Green tea (Camellia sinensis) mediated synthesis of zinc oxide $(\mathrm{ZnO})$ nanoparticles and studies on their antimicrobial activities. Int J Pharm Pharm Sci, 2014; 6(6):461-5.

Shah N, Ul-Islam M, Khattak WA, Park JK. Overview of bacterial cellulose composites: an advanced multipurpose material. Carbohydr Polym, 2013; 98(2):1585-98.

Siddhan P, Sakthivel K, Basavaraj H. Biosynthesis of bacterial cellulose imparting antibacterial property through novel bio-agents. Res J Biotech, 2016; 11(9):85-93.

Watanabe K, Tabuchi M, Morinaga Y, Yoshinaga F. Structural features and properties of bacterial cellulose produced in agitated culture. Cellulose, 1998; 5:187-200.

Yen GC, Chen HY. Antioxidant activity of various tea extracts in relation to their antimutagenicity. J Agric Food Chem, 1995; 43:27-32.

Yeom G, Yun DM, Kang YW, Kwon JS, Kang IO, Kim SY. Clinical efficacy of facial masks containing yoghurt and Opuntia humifusa Raf (F-YOP). J Cosmet Sci, 2011; 62:505-14.

Youn SW, Kim SJ, Hwang IA, Park KC. Evaluation of facial skin type by sebum secretion: discrepancies between subjective descriptions and sebum secretion. Skin Res Technol, 2002; 8(3):168-72.

Yu B, Kang S-Y, Akthakul A, Ramadurai N, Pilkenton M, Patel A, Nashat A, Anderson DG, Sakamoto FH, Gilchrest BA, Anderson RR, Langer R. An elastic second skin. Nat Mat, 2016;15:911-8.

Zhang J, Yang Y, Deng J, Wang Y, Hu Q, Li C, Liu S. Dynamic profile of the microbiota during coconut water pre-fermentation for nata de coco production. LWT-Food Sci Technol, 2017; 81:87-93.

Zhu C, Li F, Zhou X, Lin L, Zhang T. Kombucha- synthesized bacterial cellulose: preparation, characterization, and biocompatibility evaluation. J Biomed Mater Res Part A, 2014; 102:1548-57.

\section{How to cite this article:}

Indrianingsih AW, Rosyida VT, Apriyana W, Hayati SN, Darsih C, Nisa K, Ratih D. Antioxidant and antibacterial properties of bacterial cellulose-Indonesian plant extract composites for mask sheet. J Appl Pharm Sci, 2020; 10(07):037-042. 